\title{
A ritka betegségek szociálpolitikai jelentősége, a RIROSZ törekvései*
}

\author{
Pogány Gábor - Dupcsik Csaba \\ PoGÁnY GÁBOR: Ritka és Veleszületett Rendellenességgel Élők Országos Szövetsége - \\ pogany@rirosz.hu \\ DUPCSIK CSABA: ELKH Társadalomtudományi Kutatóközpont, Szociológiai Intézet, \\ KRE BTK - dupcsik.csaba@tk.hu
}

\begin{abstract}
ABSZTRAKT A 6000-8000 féle ritka betegség összességében népegészségügyi és szociálpolitikai problémát jelent. Jelen tanulmányban bemutatjuk a ritka betegségek különleges helyzetét, ezen belül a magyarországi állapotot és a javításának lehetőségeit. Egy Nemzeti Erőforrás Központ szükséges ahhoz, hogy javítsunk a ritka betegeket ellátó, különböző ágazatokhoz tartozó szolgáltatások rendszerének jelenlegi szervezettségén és hatásosságán, hogy felkészítsük az egészségügyi, oktatási, szociális szakembereket és a betegeket a legjobb ellátási gyakorlatok biztosítására és használatára. A tervszerủ ellátás célja, hogy minden ritka beteg a lehető legrövidebb idő alatt kapjon diagnózist annak érdekében, hogy időben hozzáférhessen a szükséges ellátáshoz és támogatáshoz, végeredményben csökkentve a beteg és családja megpróbáltatásait és a társadalom terheit. A szükséges szemléletmód-változáshoz fontos a betegszervezetek szerepe, amire szintén jó példát szolgáltathat a ritka betegségek területe és a RIROSZ vállalt szerepe.

Kulcsszavak: ritka betegségek, Nemzeti Erőforrás Központ, Uni-Versum Központ, Ritka Betegek Szövetsége - RIROSZ
\end{abstract}

\section{The social policy significance of rare diseases, the aspirations of RIROSZ}

ABSTRACT The 6000-8000 type of rare diseases means a public health and socio-political problem overall. In this paper we introduce the special situation of rare diseases, especially the situation in Hungary, together with the possibilities of improvement. A National Resource Centre is needed to improve the current fragmentation of services belonging to different sectors, and enable patients and health, social and educational professionals to provide and use best practice care. This will ensure that all patients with rare disease can not only be diagnosed quickly, but also have timely access to the care and support that they need, resulting a decreasing burden of families and society. The role of patient organizations is vital for the necessary changing of attitude, and the area of rare diseases including the role of HUFERDIS are also good example for this.

Keywords: rare diseases, National Resource Centre, Uni-Versum Centre, Federation of Rare Diseases Patients - HUFERDIS

\footnotetext{
* Köszönet illeti a RIROSZ és a tagszervezetei képviselőit és vezetőit, valamint az Európai Ritka Beteg Szövetség (EURORDIS) szociális politikával foglalkozó akciócsoportja (sPAG) tagjait.
} 


\section{BEVEZETÉS}

„Elöbb csináld azt, ami szükséges,

utána azt, ami lehetséges, és máris azt fogod csinálni, ami lehetetlen."

Assisi Szent Ferenc

Az európai definíció szerint egy ritka betegségként diagnosztizált állapot legfeljebb egy embert érint 2000 főből (Aymé - Rodwell 2012), azaz Magyarországon legfeljebb kb. 5000 főt tipikusan lényegesen kevesebbet - érinthet betegségenként. Ugyanakkor az Orphanet adatbázisa alapján 6172 ritka betegség létezik (Wakap et al. 2020: 165). S bár a szakirodalomban évtizedeken át elfogadottnak tekintett becslés szerint az össznépesség 6-8\%-a érintett, lásd pl. Schieppati et al. 2008, Berman 2014: 3, vagy az alapvető kézikönyvnek számító Springer-féle Rare Disease Epidemiology javított kiadását is, Groft - Posada de la Paz 2017: 5, több szakértő rámutatott arra, hogy e becslés nincs érdemi adatokkal alátámasztva. 'Egy frissnek számító tanulmányban Stéphanie Wakap és nyolc szerzőtársa „vitatja” (challange) a fenti becslést, óvatosan legalább 3,5-5,9\%-ra téve a ritka betegségekben szenvedők globális prevalenciáját (Wakap et al. 2020: 169). ${ }^{2}$

Már pusztán a következő paradoxon szemszögéből érdemes belemerülni ebbe a „számháborúba”: egyrészt a ritkaság nem csökkenti, hanem rendkívüli mértékben fokozza az egyéni szinten megjelenő problémákat; másrészt a ritka betegségek nagy száma miatt az egészségügyi és szociális problémák az össztársadalmi szinten is hatványozottan jelentkeznek. Visszatérve az abszolút számokhoz: a legfrissebb becslések alapján a 27 tagú Európai Unióban 15,6-26,4 millió ritka beteg ${ }^{3}$ élhet, a földrajzi értelemben vett Európában pedig 26,2-44,1 millió. (Ez utolsó megkülönböztetésnek van jelentősége, mivel a ritka betegek ellátására szakosodott uniós ellátóhelyeken gyakran találkozhatunk az EU-n kívülről érkező páciensekkel is.) Magyarországon a szűkebb értelemben vett érintettek ${ }^{4}$ száma legalább 342-576,4 ezer. A ritka betegségek nagy többsége (pontosan: 69,9\%-a) kizárólag gyermekkorban jelentkezik először (Wakap et al. 2020: 165), illetve a ritka betegek mintegy negyede (pontosan: $25,7 \%$-a) nagy eséllyel meghal még ötéves kora előtt, s további, jóval több mint egyharmaduk (pontosan: 36,8\%) pedig az átlagnál rövidebb élettartamra számíthat (EURORDIS 2005: 32) - következésképpen a ritka betegséggel élők között felülreprezentáltak a gyerekek és a fiatalabb korosztály. Minden esettanulmány azt mutatja, hogy egy családtag - főleg, de nem kizárólag, ha gyerekről van szó - ritka betegsége tipikusan erősen befolyásolja a közvetlen családtagok életét is. Egy kutatás szerint a ritka betegséggel élők csaknem kétharmada (pontosan: 62\%-a) naponta átlagosan több mint 2 órányi időt kénytelen a betegségéből vagy az abból adódó maradandó

\footnotetext{
${ }^{1}$ A becslés feltételezhető eredetét jelentő múlt századi amerikai jelentés az Egyesült Államok akkori népességének 4-8\%-át sorolta a ritka betegségben érintettek csoportjába (NCOD 1989: xiii). Két évtizeddel később a Committee on Accelerating Rare Diseases Research and Orphan Product Development kötete még mindig leszövegezi ugyan, hogy „nem állnak rendelkezésünkre jól alátámasztott adatok a ritka betegségekben érintett emberek számáról”, ezt követően azonban ismerteti és hivatkozza a „szokásos” adatokat. Igaz, végül megismétli: „a becsléseket nem kisérték a források elemzése vagy érdemi hivatkozása” (Field - Boat 2010: 51).

2 A világ legtekintélyesebb orvosi szaklapja, a The Lancet Child \& Adolescent Health már az említett cikk publikálásának évében ugyanezt a becslést említette, igaz, a műfaj - szerkesztőségi cikk - miatt hivatkozás nélkül (2020).

${ }^{3}$ A „ritka betegségben szenvedők” lenne a pontos megnevezés, de a továbbiakban, stilisztikai okokból szinonimának tekintjük a "ritka beteg" kifejezést is.

${ }^{4}$ A megszorítás jelentőségét lásd később.
} 
problémákkal kapcsolatos tevékenységekkel tölteni, 30\%-uknál pedig ez az idő több mint 6 óra - naponta, átlagosan (Rare Barometer 2017: 11). Nyilvánvaló, hogy a leterheltség az esetek jelentős részében a hozzátartozókat is érinti. Ha az egyszerüség kedvéért abból indulunk ki, hogy Magyarországon a nem egyfös háztartásokban átlagosan 3,4 ember él, túlnyomó többségében egymás családtagjai, akkor a fenti összefüggések azt implikálják, hogy a ritka betegségekben - a szó tágabb értelmében vett - érintettek köre potenciálisan 1,1-1,9 millió embert is jelenthet. Ezért létezik az a paradox helyzet, hogy a sokféle betegség miatt számuk olyannyira jelentős, hogy ők jelentik az egyik legnagyobb súlyos betegcsoportot, és ezért népegészségügyi prioritást, valamint az egyik legnagyobb fogyatékos csoportot is. Ugyanakkor számottevő hátrányt szenvednek a gyakoribb megbetegedésekhez képest a ritkaságból eredő plusz terhek miatt. Elég csak arra gondolni, hogy a ritkaságból következően egy-egy konkrét betegséggel az egészségügyi dolgozók döntő többsége pályafutása során soha nem találkozott, így nem csoda, ha az első tünetek észlelése és a helyes diagnózis megszületése előtt általában évek, akár évtizedek telnek el (The Voice 2009: 43). Nyilvánvalónak tünik, hogy egy Magyarország méretű országban a 6172 ritka betegség jelentős részében a szakértőnek tekinthető orvosok száma a néhány és a nulla között mozog, ami gyakran logisztikai problémákat vagy például a szakértők életrajzi eseményeinek (szülés és gyes, nyugdíj, külföldi munkavállalás stb.) való fokozott kiszolgáltatottságot is implikálhat.

A ritka betegségben szenvedők és családjaik tehát az esetleges társadalmi diszkriminációtól függetlenül is egy hátrányos helyzetü kisebbség tagjainak tekinthetők. S mint általában minden hátrányos helyzetü kisebbség esetében, itt is azt látjuk, hogy velük kapcsolatban a teljes népességet kiszolgáló intézményrendszer minden gyengesége - gyakran kiélezett formában - jelentkezik, miközben annak esetleges erősségei itt érvényesülnek a legkevésbé. Ezért egy a ritka betegséggel élő kliensekért dolgozó civil szervezet számára elsődleges cél az esélyegyenlőségük javítása. Az általános gyakorlat szerint az esélyegyenlőség az emberek specifikus szükségleteinek kielégítését jelenti úgy, hogy megszüntetjük a gátakat, melyek megakadályozzák a társadalomban történő teljes részvételüket. A ritka betegséggel élö emberek esetén ez olyan szociális lehetőségeket jelent, amikor biztosítjuk számukra az egyenlő hozzáférést a diagnózishoz, az egészségügyi és szociális ellátáshoz, kezeléshez, gondoskodáshoz.

Egy ritka betegséggel élő klienssel szembekerülő szakember vagy szervezet sokszor érezheti úgy, hogy a lehetetlenre vállalkozik, amikor segíteni próbál. Nehéz a dolga a döntéshozóknak is az általános információhiány miatt, ha megalapozottan szeretne döntéseket hozni, ellátást szervezni. Hasonló módon maga a beteg és családja is szinte lehetetlen dolgokkal birkózik, míg megtanul „térkép nélkül közlekedni egy sivatagban”.

Mindennek ellenére az utóbbi évtizedekben a szívós hazai és nemzetközi együttműködés eredményeként jelentős haladás történt ezen az előzőekben elhanyagolt területen is. Így bár a „sivatagba kerülést” nem tudjuk elkerülni, de térképet, szótárt és túlélő felszerelést már sokszor tudunk adni. Ezért tevékenykedik a Ritka és Veleszületett Rendellenességgel élők Országos Szövetsége, a RIROSZ is. 


\section{A KIHÍVÁS: PROBLÉMÁK AZ EGÉSZSÉGÜGY ÉS A SZOCIÁLIS ÜGY TERÜLETÉN}

A ritka betegségek (RB) olyan életet fenyegető vagy krónikus rokkantságot okozó betegségek, amelyekkel való foglalkozás speciális, összetett feladatot jelent. Hiába szenvedhet egy-egy betegségben nagyon kevés érintett, összességükben a rendkívül heterogén, súlyos, multiszisztémás ritka betegek tehát nem ritkák, ezért kezeli az Európai Unió is kiemelt prioritásként a jogaik és esélyegyenlőségük biztosítását (Aymé - Rodwell 2012).

Sajnos az Európában alkalmazott BNO-10 rendszerben (Betegségek Nemzetközi Osztályozása) csak kb. 500 különböző ritka betegségnek vagy csoportnak van egyedi kódja, ezért a többi sok ezer a statisztikáink és finanszírozási rendszereink számára láthatatlan, akadályozva az optimális ellátásszervezést (Pogány 2017). Így sem a Nemzeti Egészségbiztosítási Alapkezelő (NEAK, régen OEP) sem a Nemzeti Népegészségügyi Központ (NNK, régen ÁNTSZ), sem pedig a Központi Statisztikai Hivatal (KSH) adatbázisaiban nem szerepelnek.

A tüneti kezelések gyors fejlödése ellenére sajnos napjainkban a ritka betegségek csupán 6\%-a gyógyítható véglegesen, azaz az oki terápia az esetek többségében nem megoldott (Orphanet Report Series 2020). Ezért sok esetben az egészségügy csak egy bizonyos pontig tud segíteni, azután már csak a többi ágazat (szociális, családügyi, oktatási, fogyatékosságügyi, munkaügyi) képes az érintett családok életminőségén javítani. Az EC3 nevü összeurópai felmérés alapján megállapíthattuk, hogy az egészségügyre vonatkozó hazai adatok - néhány kivételtől eltekintve - az európai átlag közelébe esnek (Pogány 2010). Nem ez a helyzet a szociális ügyek terén, ahol a ritka betegséggel élő kliensekre vonatkoztatva egyik legrosszabb a helyzetünk a tagállamok között, mind a szociális ellátások elérhetősége, mind a velük való megelégedettség vonatkozásában. Sajnos a beteg és családja gyakran érezheti úgy, hogy a különbözö ágazati labirintusokban (egészségügy, szociális szolgáltatások, oktatás, foglalkoztatás stb.) és közöttük, pingponglabdaként pattogtatják a különböző szolgáltatók. A ritka betegséggel élők még a hasonló gondokkal küzdő gyakori krónikus betegekkel szemben is hátrányban vannak, mivel az ellátó rendszerek végfelhasználóit (a betegek és családjaik) vizsgáló tanulmány szerint a gyakori krónikus betegek problémás ellátásával való megelégedettség is 70\%-ban jobb volt, mint a ritka betegséggel élők esetén (Rare Barometer 2021).

A szociális ügy terén a fentiek ellenére még sokszor ismeretlen a ritka betegséggel élő kliens fogalom. A szociális ellátó rendszer a klasszikus fogyatékos kategóriákkal foglalkozik, így a ritka betegséggel élő kliensek okozta kihívásokra nem mindig ad választ. A szociális ellátások többsége is BNO-hoz kötött (az ügyvitel gyorsítására), ezért a sok ezernyi ritka betegséggel élő első körben automatikusan elesik a lehetséges juttatásoktól. Mindezekért szükség van egy ágazatközi információs és koordinációs központra, hogy betegek és családjaik eligazodhassanak az egészségügyi és szociális stb. szolgáltatások labirintusában, és megkaphassák a szükséges személyre szabott ellátást.

Az egyenként keveseket érintő betegségek ismereteinek hiánya miatt kevés a hozzáértő szakember, a betegek egyáltalán nem, vagy későn (akár 30 év eltelte után) kapnak diagnózist, ezért megfelelő kezelésre sincs mód (Földvári et al. 2012). A sok felesleges kezelés hatalmas terhet jelent a társadalom számára, míg a ritka betegséggel küzdők életét különösen a sorstársak, a megfelelö gyógyszerek, és az ellátás hiánya is nehezíti. A betegeknek rosszak az életkilátásaik, jelentősen alacsonyabb a várható élettartamuk. Sok esetben önellátásra képtelenek, fo- 
lyamatos felügyeletet és ápolást igényelnek, a felnőttkort megérők számos esetben képtelenek munkát vállalni. A súlyosság és gyógyíthatatlanság reményvesztettséghez vezethet, ezért a családok sokszor felbomlanak, nehéz gazdasági helyzetbe sodródnak, elszigetelődnek, a társadalom perifériájára szorulnak (Götz, I. - Götz, M. 2000). Így jelentős társadalmi terhek jelentkeznek minden ágazat ellátórendszerében, valamint az ellátórendszereken kívül (Linertová et al. 2017).

Ezért a problémák ilyen sokaságára esetükben csak az integrált ellátás, azaz a teljes körü, holisztikus megközelítés és multidiszciplináris, koordinált (egészségügyi, szociális, oktatási, foglalkoztatási stb.) ellátási mód hozhat eredményt. Azért is szükséges a jobb ágazatközi koordináció, mert az egyik ágazatban végzett jó munka a másik ágazatban eredményezhet megtakarítást (Rashdan - Brodszky 2020). Ezért került az integrált ellátás hazánk második Ritka Betegségekkel foglalkozó Nemzeti Tervének középpontjába (melynek a kidolgozása most zajlik). A nemzetközi példák alapján az integrált ellátás és koordináció fö letéteményese egy ún. Nemzeti Erőforrás Központ létrehozása, mely a RIROSZ jelenlegi legfontosabb célkitüzése.

A ritka betegséggel élő kliensekre jellemző egyenlőtlenségnek és az emberi jogok sérülésének felismerése a nemzetközi jogalkotásban is nyomon követhető. Michelle Bachelet (2019), az ENSZ Emberi Jogi Főbiztosa jelentésében kiemeli: „....az egészségügyi ellátás és szolgáltatások elérhetősége továbbra is alacsony, és minőségük gyenge, különösen a kapcsolódó károsodások tekintetében. A ritka betegségek gyakran megbélyegzést és megkülönböztetést vonzanak, és sok ritka betegségben szenvedő személyt kizárnak a foglalkoztatásban való részvételből, valamint a társadalomba történő teljes és produktív beilleszkedésből." Az alábbi felsorolás mutatja az utóbbi évek fontosabb dokumentumait ezen a területen a teljesség igénye nélkül:

- Az EU Bizottság közleménye a hatékony, hozzáférhető és alkalmazkodóképes egészségügyi rendszerekröl, 2014;

- Európai fogyatékosságügyi stratégia (2010-2020): egy megújított elkötelezettség az akadálymentes Európa megvalósítása iránt, 2010;

- ENSZ 17 fenntartható fejlesztési célja, 2015;

- Ritka betegségek: az egyik legjelentősebb kielégítetlen egészségügyi szükséglet, EUpublikáció, 2017;

- Szociális Jogok Európai Pillére, 2017;

- Tokiói ENSZ nyilatkozat az egyetemes egészségügyi ellátásról, 2017;

- Az EU Bizottság közleménye az egészségügy és az ellátás digitális átalakításának a digitális egységes piacon való lehetővé tételéről, 2018.

Az integrált ellátás sikeréhez szükséges tényezőket mérte fel az Európai Unió Egészségügyi Rendszerek Hatékonyságát Felmérő Szakértői Csoportja 2017-ben, melyeket az első ábra foglal össze. 


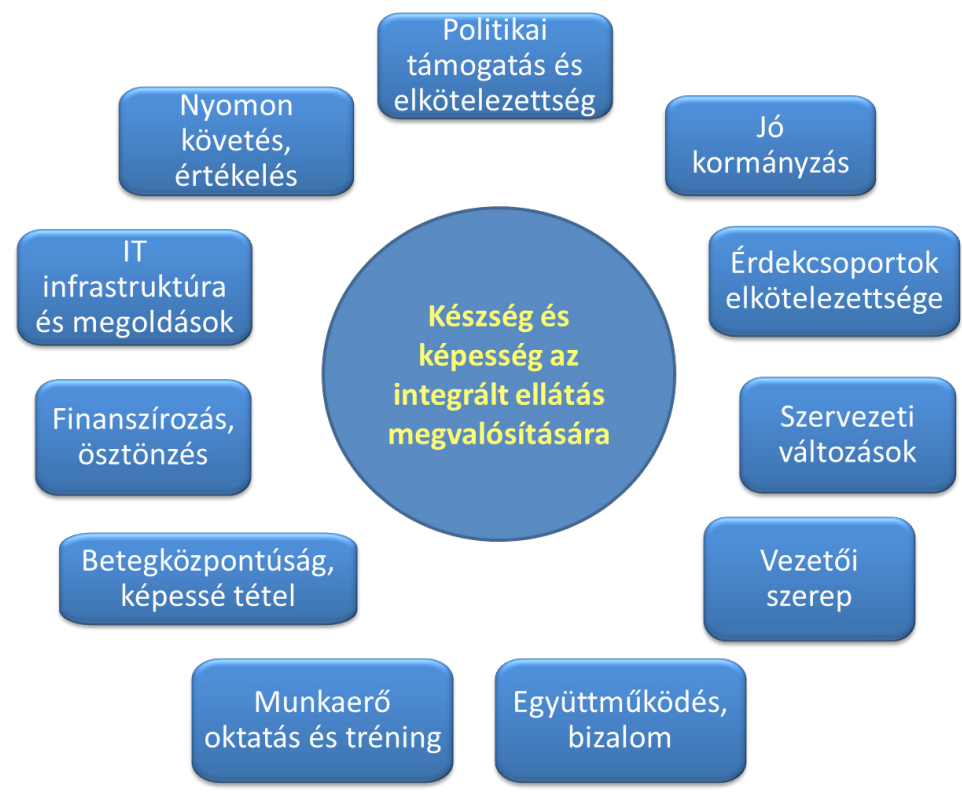

1. ábra Az integrált ellátás sikeréhez szükséges tényezők

Forrás: BLOCKS. Tools and methodologies to assess integrated care in Europe. Report by the Expert Group on Health Systems Performance Assessment. https://ec.europa.eu/health/sites/health/files/ systems_performance_assessment/docs/2017_blocks_en_0.pdf

Tekintettel a téma fontosságára, a krónikus multimorbid betegek több szolgáltató együttműködésével megvalósuló integrált ellátási modelljeit vizsgáló újabb európai uniós projekt, a SELFIE 2020 program született https://www.selfie2020.eu/. Ennek keretében több hazai workshop is lezajlott, megvitatva az értékelhető magyarországi programokat vagy modellkísérleteket, valamint a SELFIE konzorcium többi országában azonosított projekteket és azok relevanciáját a hazai egészségügyi rendszerben. Így a RIROSZ kezdeményezésére megvitatásra került a Ritka Betegségek Nemzeti Erőforrás (Uni-Versum) Központja létrehozásának lehetősége is. A program keretén belül azonosították az integrált ellátás fö gátjait az EU közép- és keleteurópai országai érintett érdekcsoportjainak közreműködésével, amit a következő ábra mutat. 
2. ábra Az integrált ellátás fö gátjai az EU közép- és kelet-európai országaiban

Forrás: Pitter, J. et al. 2019

Az Európai Ritka Beteg Szövetség (EURORDIS) szociális politikával foglalkozó akciócsoportja megfogalmazott egy ajánlást a ritka betegek holisztikus, személyközpontú ellátásáról. Ebben a ritka betegséggel élők és gondozóik mindennapi teljesítetlen szükségletei ellátásához három fö pillért különítettek el:
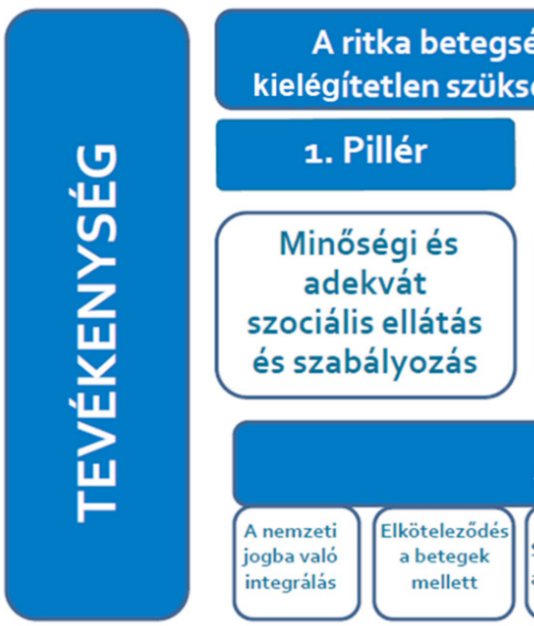

A ritka betegséggel élők és gondozóik mindennapi, oktatási stb. rendszerek és költségvetések; gyenge szektorközi

Bizonytalan anyagi anyagi ösztönzők az új szerepek részére; társfinanszírozás a betegek részéről nem elfogadható/traszparens

A gondozási folyamatban az E-health eszközök alacsony elfogadottsága Új professzionális szerepek alacsony elfogadottsága (különösen a nem orvosi szerepeké)

Kutatók és értékelők korlátozott hozzáférése a betegszintű adatokhoz

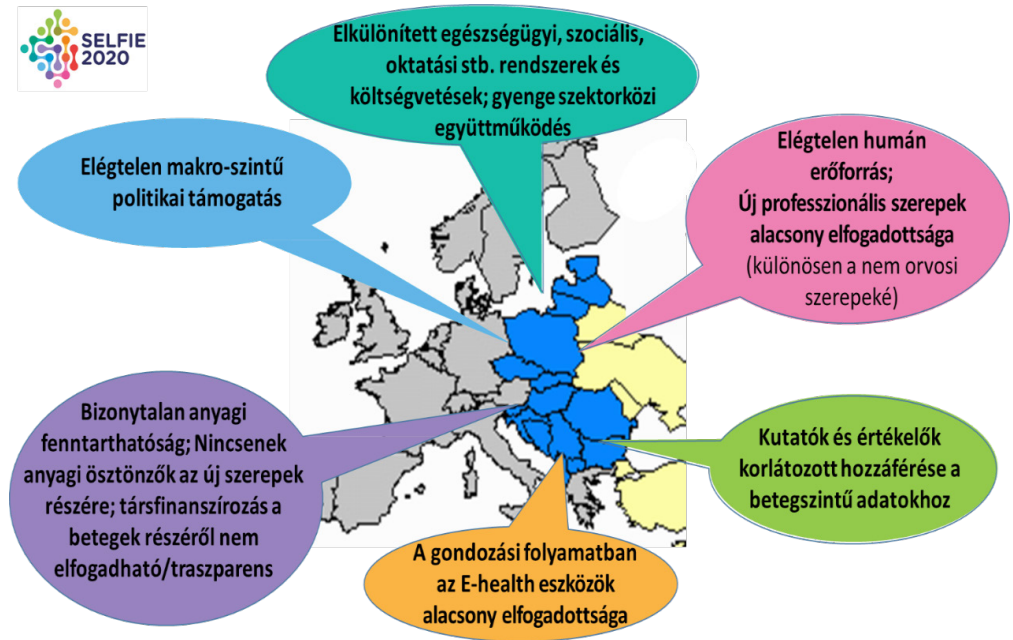


Ha a fenti tevékenységeket sikerül megvalósítani, akkor a holisztikus integrált ellátásnak a következő eredményei várhatók:
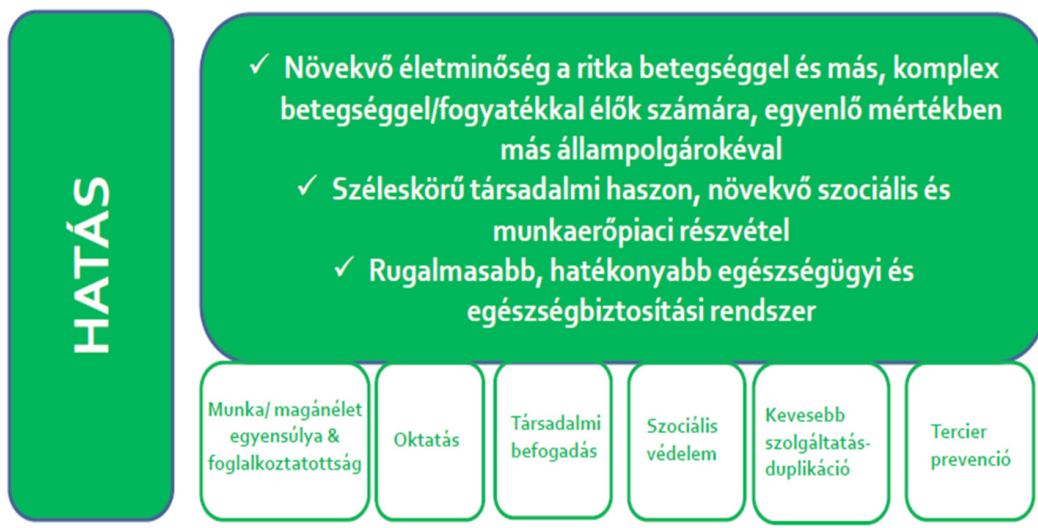

4. ábra A ritka betegséggel élők integrált ellátásának várható eredményei Forrás: Achieving Holistic Person-Centred Care to Leave No One Behind. A position paper by EURORDIS and its Members | May 2019. https://www.eurordis.org/carepaper

Sajnos az integrált ellátás megvalósításához szükséges ágazatközi együttműködést számos gátló tényező nehezíti:

- Rengeteg a bürokratikus akadály;

- Nem kompatibilis és nem interoperábilis adatbázisok, regiszterek stb.;

- Nem felhasználóbarát programok (pl.: CPMS Clinical Patient Management System);

- Elkülönült információs, finanszírozási silók.

Ezért is fontos a tervezett Erőforrás Központ információs és koordinációs szerepe.

\section{A RITKA BETEGSÉGEK NEMZETI ERÖFORRÁS (UNI-VERSUM) KÖZPONTJA A MEGOLDÁSI RENDSZER LEGFONTOSABB ELEME}

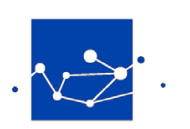

A fentiek alapján, a nemzetközi gyakorlatnak (Council Recommendation 2009) és a Ritka Betegségekre vonatkozó Nemzeti Tervünknek megfelelöen, Románia és Horvátország után hazánkban is fontos cél ennek a Központnak a létrehozása. A nemzet érdeke, hogy növeljük a Kárpát-medencéUNI-VERSUM ben élö ritka betegségben szenvedö magyarok esélyét a koraibb diagnózisra és megfelelő ellátásra, ezáltal jelentősen javítva mind ezen egyének és családjaik helyzetén, mind pedig a társadalom egészségügyi forrásainak felhasználásának hatékonyságán. Fő cél, hogy megfelelő szakmai gárdával, a sérült vagy hiányzó funkciók minél korábbi felismerésre, gyógyításra, (re)habilitációra kerülhessenek. Az integrált megközelítési módot ún. koordinációs csoport esetmenedzselésével valósítja meg. 
Az EU több éves InnovCare programjában (https://innovcare.eu) a gyakorlat során határozták meg az intenzív esetmenedzser szerepeit az Erőforrás Központban dolgozó koordinációs csoport tagjaként:

- Egyedi, stabil kapcsolat

- Meghallgat, informál, megerősíti a beteget és családját

- Tudást, eszközöket ad, létező erőforrásokhoz vezet

- Elősegíti az egészségügyi műveltséget és a kezelések betartását

- Csökkenti a gondozási terheket

- Felméri, monitorozza, megfigyeli a szükségleteket

- Holisztikus, betegközpontú gondozás-tervezés és koordináció:

- Egyszerüsíti a kliensutakat, folyamatos támogatást nyújt a betegnek, a családnak és a szakembereknek

- Az információ és a tudás középpontja - jellemző a magas szakmai követelményszint (képzettségi szint, felkészültség, az adott klienscsoportra vonatkozó speciális többlettudás, kompetencia)

- Tájékoztatja, támogatja és megerősíti a gondozásban résztvevő szakembereket

- A szolgáltatók közötti koordináció megkönnyítése, szolgáltatói hálózatok szervezése

- Az elkerülhető magas kockázatú helyzetek megelőzése és az egészségügyi szolgáltatások túlzott, szükségtelen igénybevételének korlátozása

- Olyan munkamódszerek kidolgozása, amelyek támogatják a betegek és családok megerősítését

A Központ tevékenységével jelentős terhet vesz le az ellátórendszerekröl, biztosítva a betegeknek a megfelelö belépési pontok, kliensutak kiválasztását. Részt vesz az egészségügyi és a szociális, a helyi és a nemzeti, európai szolgáltatások közötti rések áthidalásában, javítva a ritka vagy komplex betegségekkel élők számára nyújtott szolgáltatásokat, ahogy az alábbi ábra mutatja:

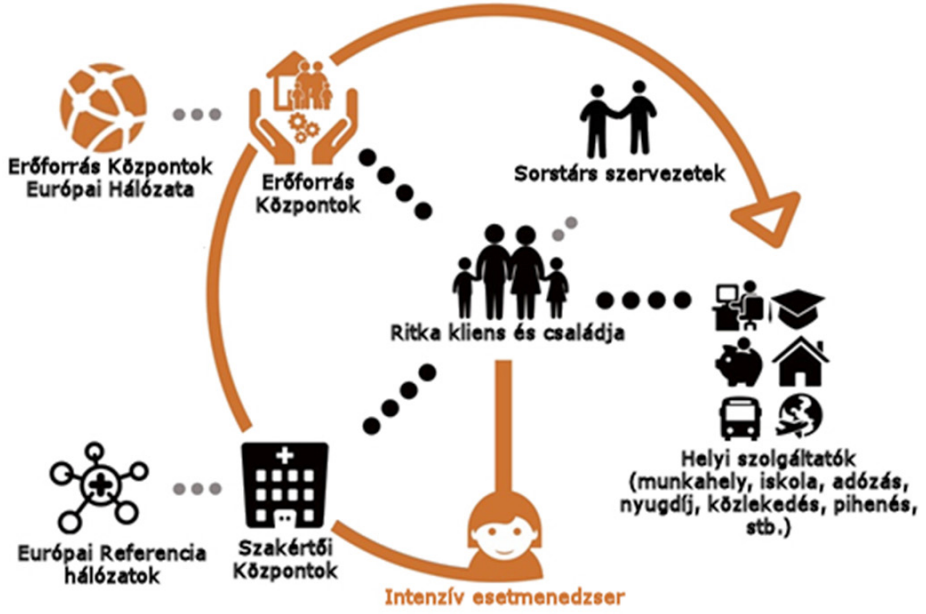

5. ábra Az erőforrás központok helye a ritka betegséggel élők integrált ellátásában

Forrás: Presentation: Bridging the gaps between health, social and local services to improve care of people living with rare and complex conditions (2018).

https://innovcare.eu/innovcare-project-presentation/ 
Az Erőforrás Központ jellemzői:

- a Központ célja egy egyablakos, személyközpontú, integrált szolgáltatás nyújtása a meglevö emberi eröforrásokhoz tartozó (egészségügyi, szociális, családügyi, oktatási, foglalkoztatási stb.) szolgáltatások kiegészitésére és összehangolására.

- Ágazatközi információs és koordinációs csomópont az egészségügyi és szociális ellátási, kutatási és oktatási területek között, a legújabb digitális eszközöket használva.

- Csökkenti a hatástalan vagy nem megfelelő kezelések számát, redukálja a diagnosztikai késedelmet, mérsékli a többszörös, ismételt, szükségtelen egészségügyi kezelések gyakoriságát s így jelentösen növeli a költséghatékonyságot.

- Holisztikus és specifikus szolgáltatásokat és támogatásokat nyújt, hidat képezve a betegek és családjaik, valamint a különböző érintett szakmák, szolgáltatások és szakemberek között, javítva a kliensút szervezést.

- Részt vesz az irányelvek, jó gyakorlatok, képzések, oktatási lehetőségek kidolgozásában.

- Tréningeket és oktató kurzusokat szervez, lebonyolít, mint tudáskezelési csomópont.

- A jó gyakorlatokat alkalmazza, megosztja, valamint részt vesz a harmadlagos megelözésben iránymutatások révén.

- Mindehhez együttműködik az összes ágazat minden kapcsolódó érdekcsoportjával és szervezetével hazai és nemzetközi téren egyaránt. E kapcsolatrendszer részei lehetnek pl. a 6. ábrán látható intézmények, szervezetek.

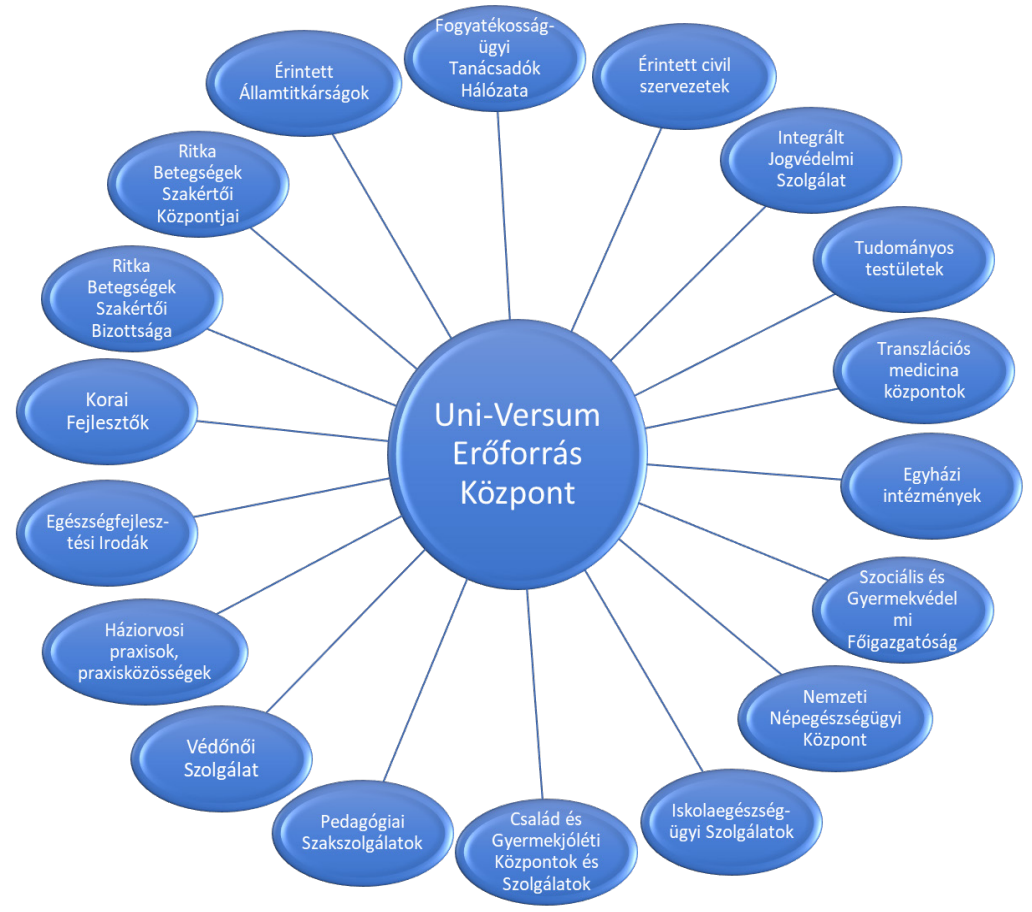

6. ábra Az erőforrásközpont kapcsolatrendszere

Forrás: Saját szerkesztés 
A Központ jelenleg legvalószínűbb helyszíne az Országos Korányi Pulmonológiai Intézet, ahol zöldmezős beruházásként valósulna meg (1121 Budapest, Korányi Frigyes út 1.), melyet az Intézet és az EMMI vezetése is támogat.

A Központ létesítéséhez szükséges Megvalósíthatósági Tanulmány elkészítése most folyik. A Központ új módszereket, szemléletet vezet be a meglevő rendszerek kiegészítésére, ezért ún. diszruptív innovációnak tekinthető. Ez az egészségügyben olyan típusú innováció, amikor új hálózatokat és új szervezeteket hozunk létre, új értékkészleten alapulva, új szereplők bevonásával, ami lehetővé teszi az egészségügyi eredmények javítását, és egyéb értékes célok jobb elérését, mint pl. az esélyegyenlőség vagy a hatékonyság.

Az intézmény része egy akadálymentes, 20 ágyas szállóhely a megfelelő kiszolgáló egységekkel (speciális étkező diétázóknak stb.), ahol a családok a fejlesztések mellett iránymutatást kapnak az integrált ellátási lehetőségekről, helyekről. Egyhetes „tanfolyamon” a család minden tagja személyre szabottan azt is megtanulja, hogyan kell együtt élni az adott beteggel/betegséggel.

A Központ azonnal belépne a RareResourceNet-be, az Európai Ritka Betegségek Erőforrás Központjai Hálózatába, mely az egészségügyben tevékenykedő Európai Referencia Hálózatok széles értelemben vett szociális területen müködő partnerhálózata.

\section{KÖVETKEZTETÉS}

Az áttekintett adatok bemutatták, hogy mind hazai, mind pedig európai téren súlyos nehézségekkel kell a ritka betegséggel élőknek megküzdeniük, rámutatva a beavatkozást igénylő területekre. A sokszor gyógyíthatatlan és sok szenvedéssel járó ritka betegségek érintettjei nemcsak a társadalom többségével, hanem a többi beteggel szemben is hátrányos helyzetben vannak, az általános információhiány és következményei miatt. Ugyanakkor nekik is joguk van a többiekével azonos esélyü gyógyuláshoz az igazságosság, egyenlőség és szolidaritás elve alapján.

A számukra szükséges holisztikus, integrált ellátás és koordináció fö eleme a nemzetközi tapasztalatok alapján is a Ritka Betegségek Nemzeti Erőforrás (Uni-Versum) Központjának létrehozása. Ez a személyközpontú, „egyablakos” új szolgáltatás kiegészíti a meglévő emberi erőforrásokhoz tartozó (egészségügyi, szociális, családügyi, oktatási, foglalkoztatási stb.) szolgáltatásokat. Az ágazatközi koordináció javításával csökkenti az egészségbiztosítás és szociális ellátás költségeit. A források sokkal hatékonyabb felhasználásával a kormányzat minimális ráfordítással, a rendszerben meglévő források racionalizálásával maximális hasznosulást érhet el. Ehhez a RIROSZ és tagszervezetei minden területen a lehető legnagyobb mértékben igyekszik hozzájárulni. 


\section{IRODALOM}

Aymé, S. - Rodwell, C. (eds.) (2012): 2012 report on the state of the art of rare disease activities in Europe of the European Union Committee of Experts on Rare Diseases. Part I.: Overview of rare disease activities in Europe. European Union, Luxemburg.

https://doi.org/10.2772/ 50554

Berman, Jules J. (2014) Rare Diseases and Orphan Drugs: Keys to Understanding and Treating the Common Diseases. London - Waltham, MA - San Diego, CA: Academic Press.

Council Recommendation of 8 June 2009 on an action in the field of rare diseases. Official Journal of the European Union, C151, 7-10.

EURORDIS (2005): European Conference on Rare Diseases. Luxembourg 21-22 June 2005. Brussels: EURORDIS: Rare Diseases Europe. Available:

https://www.eurordis.org/IMG/pdf/EN-ECRDtotal-2.pdf (utolsó letöltés: 2021.04.21.)

Field, Marilyn J. - Boat, Thomas F. (eds.) (2010): Rare Diseases and Orphan Products: Accelerating Research and Development. Washington DC: The National Academies Press.

https://doi.org/10.17226/12953

Földvári, A. - Szy, I. - Sándor, J. - Pogány, G. - Kosztolányi Gy. (2012): Diagnostic delay of rare diseases in Europe and in Hungary. [A ritka betegségek diagnosztikájának késedelme Európában és Magyarországon.] Orv. Hetil., 153(30): 1185-1190.

https://doi.org/10.1556/OH.2012.29418

Götz, I., Götz, M. (2000): Cystic fibrosis psychologiocal issues. Paediatric Respiratory Reviews, I, 2, 121-127. https://doi.org/10.1053/prrv.2000.0033

Groft, Stephen C. - Posada de la Paz, Manuel (2017): Rare Diseases: Joining Mainstream Research and Treatment Based on Reliable Epidemiological Data. In: Posada de la Paz, Manuel - Taruscio, Domenica - Groft, Stephen C. (eds.): Rare Diseases Epidemiology: Update and Overview. Second Edition. Cham: Springer, 3-21.

https://doi.org/10.1007/978-3-319-67144-4

Linertová, R. - García-Pérez, L. - Gorostiza, I. (2017): Cost-of-Illness in Rare Diseases. In: Posada de la Paz, M. - Taruscio, D. - Groft S. (eds): Rare Diseases Epidemiology: Update and Overview. Advances in Experimental Medicine and Biology, vol 1031. Springer, Cham, 283297. https://doi.org/10.1007/978-3-319-67144-4_17

NCOD (National Commission on Orphan Diseases) (1989): Report of the National Commission on Orphan Diseases. Rockville, MD: Public Health Service, U.S. Department of Health and Human Services. https://rarediseases.info.nih.gov/files/report_of_the_national_ commission_on_orphan_diseases_february_1989.pdf (utolsó letöltés: 2021. 04.21.)

Orphanet Report Series - Lists of medicinal products for rare diseases in Europe. November 2020.

http://www.orpha.net/orphacom/cahiers/docs/GB/list_of_orphan_drugs_in_europe.pdf (utolsó letöltés: 2021.04.21.)

Pitter, J., et al. (2019): Transferability of most promising ICC models, financial incentives, and performance monitoring to Central and Eastern Europe (CEE). 
https://ec.europa.eu/research/participants/documents/downloadPublic?documentlds=0 80166e5c708935f\&appld=PPGMS (utolsó letöltés: 2021.04.21.)

Pogány, G. (2010): The present situation of rare diseases in Central/Eastern Europe? The role of patient organisations. Orphanet J. Rare Dis., 5(Suppl 1), O30. https://doi.org/10.1186/ 1750-1172-5-S1-O30

Pogány, G. (2017): A ritka betegségek ellátásának aktuális kérdései. Orv Hetil. 158(47): 18511856. https://doi.org/10.1556/650.2017.30908

Rare Barometer (2017): Juggling care and daily life: The balancing act of the rare disease community: A Rare Barometer survey. Paris: EURORDIS (Paris Office). Available:

http://download2.eurordis.org.s3.amazonaws.com/rbv/2017_05_09_Social\%20survey\% 20leaflet\%20final.pdf (utolsó letöltés: 2021.03.20.)

Rare Barometer (2021): Improve our experience of health care! Available at: https:// download2.eurordis.org/rbv/HCARE/HCARE_FS_long.pdf. (utolsó letöltés: 2021.04.21.)

Rashdan, O., Brodszky, V. (2020): Productivity Loss in Patients With Chronic Diseases: A Pooled Economic Analysis of Hungarian Cost-of-Illness Studies. Value in Health Regional Issues. 22(C): 75-82. https://doi.org/10.1016/j.vhri.2020.07.572

Schieppati, A. - Henter, Jl. - Diana, E. - Aperia A. (2008): Why rare diseases are an important medical and social issue. Lancet, 371: 2039-2041. https://doi.org/10.1016/S0140-6736(08) 60872-7

The Lancet Child \& Adolescent Health (2020): Rare diseases: clinical progress but societal stalemate. The Lancet Child \& Adolescent Health, 4(4): 251.

https://doi.org/10.1016/s2352-4642(20)30062-6

The Voice (2009): The Voice of 12,000 Patients. Experiences and Expectations of Rare Disease Patients on Diagnosis and Care in Europe. A report based on EurordisCare 2 and EurordisCare 3 Surveys. Boulogne-Billancourt: EURORDIS: Rare Diseases Europe. http://www.eurordis.org/ IMG/pdf/voice_12000_patients/EURORDISCARE_FULLBOOKr.pdf (utolsó letöltés: 2021. 03.20.)

Wakap, S. N. - Lambert D. M. - Olry, A. - Rodwell, C. - Gueydan, C. - Lanneau, V. - Murphy, D. - Cam, Y. L. - Rath, A. (2020): Estimating cumulative point prevalence of rare diseases: analysis of the Orphanet database. Eur. J. Hum. Genet., 28: 165-173.

https://doi.org/ 10.1038/s41431-019-0508-0 